УДК 663.54

\title{
The Study of the influence of various factors on the ethanol production by the Hanseniaspora opuntiae
}

\author{
S. KESHTKAR ${ }^{1}$, D. Sc O. Ya. MEZENOVA ${ }^{2}$ \\ Kaliningrad State Technical University \\ S. HOSSEINI ${ }^{3}$ \\ Alzahra University, Tehran, Iran \\ E. ROMIANI ${ }^{4}$ \\ Tehran University, Tehran, Iran \\ ${ }^{1}$ keshtkar.bio@gmail.com, ${ }^{2}$ mezenova@klgtu.ru, ${ }^{3}$ saba.hoseyny@gmail.com, ${ }^{4}$ eroomiani@ut.ac.ir
}

The amount of ethanol production in fermentation process, depends on environmental factors. In order to study the influential factors in producing ethanol by strain of Hanseniaspora opuntiae, the amount of ethanol production was measured in YPD culture medium (1\% yeast extract, $2 \%$ peptone, $2 \%$ glucose, in distilled water) at different temperature and pH and also in the presence of specific volume of different carbon sources including glucose, sucrose, fructose syrup, glucose syrup, molasses and whey, and different nitrogen sources such as ammonium phosphate, ammonium sulfate, industrial urea, ammonium nitrate, peptone and amine-chloride. In order to optimize the conditions of ethanol production and to gain maximum production rate by yeast strain, test design method with Response Surface Method was used, aiming at achieving better results, significant decrease in the number of tests and optimizing production conditions. Using the Placket-Burman option of Minitab ${ }^{\odot}$ software, effectual factors were screened with. To determine the amount of ethanol produced used HPLC technique. The results showed that among the measured factors, nitrogen source has the most effects in producing ethanol by studied strain and the minimum effect was related to ph. Also, among the carbon sources, the highest production occurred in the presence of sucrose and molasses, and among nitrogen supplies the best performance in producing ethanol occurred with peptone and ammonium nitrate.

Keywords: alcohol fermentation, ethanol, Hanseniaspora opuntiae, nitrogen, carbon.

Article info:

Received 31/01/2019, accepted 08/04/2019

DOI: $10.17586 / 1606-4313-2019-18-2-49-54$

Article in English

For citation:

Keshtkar S., Mezenova O. Ya., Hosseini S., Romiani E. The Study of the influence of various factors on the ethanol production by the Hanseniaspora opuntiae. Vestnik Mezhdunarodnoi akademii kholoda. 2019. No 2. p. 49-54.

\section{Изучение влияния различных факторов на выработку этанола штаммом Hanseniaspora opuntiae}

\author{
С. КЕШТКАР ${ }^{1}, \partial-p$ техн. наук О. Я. МЕЗЕНОВА ${ }^{2}$ \\ Калининградский государственный технический университет \\ С. ХУСЕЙНИ \\ Университет Алзахра, Иран, Тегеран \\ Э. РОМИАНИ \\ Тегеранский университет, Иран, Тегеран \\ ${ }^{1}$ keshtkar.bio@gmail.com, ${ }^{2}$ mezenova@klgtu.ru, ${ }^{3}$ saba.hoseyny@gmail.com, ${ }^{4}$ eroomiani@ut.ac.ir
}

Объем производимого спиртовым брожением этанола во многом определяется факторами окружающей среды. В настоящем исследовании использован итамм Напsеnіaspora орипtiaе, который был выделен от поврежденного винограда после отбора проб и скрининга. Для изучения факторов, влияющих на выработку этанола этим итаммом, измеряли количество продуцируемого этанола в культуральной среде ҮРD (состав: $1 \%$ дрожжжевой экстракт, $2 \%$ пептон, $2 \%$ глюкоза, дистиллированная вода) при варьировании различных факторов: температура, рН, наличие различных источников углерода, включая глюкозу, сахарозу, фруктозный сироп, глюкозный сироп, патоку и сыворотка в определенных объемах, и также наличие различных источников азота, таких как фосфат аммония, сульфат аммония, промышленная мочевина, нитрат аммония, пептон и хлорид аммония. Для оптимизации условий производства этанола и получения максимальной его производительности по названному штамму дрожжей, применяли метод планирования и оптимизации экспериментов Response Surface Method, направленный на достижение наилучших результатов при значительном уменьиении количества тестов и оптимизацию процесса в производственных условиях. Для этого использовали опцию РІаскеt-Виттап 
программного обеспечения Minitab $^{\odot}$, предварительно были проанализированы наиболее эффективные факторы внешней среды. Для определения количества производимого этанола применяли метод высокоэффективной жсидкостной хроматографии (ВЭЖХ). Результаты показали, что среди измеренных факторов источник азота оказывает наибольщее влияние на продуцирование этанола исследуемым штаммом, а минимальный эффект был связан с изменением рН. Наиболее эффективным источником углерода для продуцирования спирта данным штаммом оказались сахароза и патока, а среди источников азота наивысшая производительность в продуцировании этанола была достигнута при использовании пептона и нитрата аммония.

Ключевые слова: спиртовое брожение, этанол, штамм Hanseniaspora opuntiae, азот, углерод.

Информация о статье:

Поступила в редакцию 31.01.2019, принята к печати 08.04.2019

DOI: $10.17586 / 1606-4313-2019-18-2-49-54$

Язык статьи - английский

Ссылка для цитирования:

Keshtkar S., Mezenova O. Ya., Hosseini S., Romiani E. The Study of the influence of various factors on the ethanol production by the Hanseniaspora opuntiae. // Вестник Международной академии холода. 2019. № 2. С. 49-54.

\section{INTRODUCTION}

Unreasonable and extreme use of fossil fuels, will not only deprived the next generation from these sources that had been made during millions of years, but also will cause severe increasing of pollution [1]. In this vein, one of fundamental ways that help us to produce fuel and not to utilize fossil fuel extremely and at the same time reduce environmental pollution, is to use alternative fuels. One of the most important biofuel is bioethanol that is produced from crops like sugar cane, wheat, corn and sugar beet [2].

Ethanol is a kind of alcohols with $\left(\mathrm{C}_{2} \mathrm{H}_{5} \mathrm{OH}\right)$ chemical formula that is known with other names such as Ethylalcohol and Cereal alcohol. Ethanol is the second element in aliphatic alcohols series that solve easily in water and organic solvents. Ethanol is a colorless liquid with a pleasant odor [3]. Freezing point of Ethanol is -115 and its boiling point is +78 centigrade degrees, its specific weight is 0.79 gram on milliliter in $20^{\circ} \mathrm{C}$ [4]. In fact, bioethanol is an ethanol that is produced from crops waste product by fermentation processes with bacteria or yeast, sugar cane, sugar beets, wheat and barley are some examples of these crops. Ethanol is utilized in the fuel, food, pharmaceutical and cosmetics industries but its usage as a perfect fuel or in combination with gasoline is increasing [5]. Ethanol fermentation process that is known as alcoholic fermentation, is a biologic process that leads to consume sugars like glucose, fructose or sucrose, and produces the molecule of ethanol as output [6].

Among all the yeasts, Saccharomyces family is one of the best options in ethanol production. The yeast of Saccharomyces is one of the few yeasts with the capacity to grow rapidly both under aerobic and anaerobic conditions [7]. It is a sort of yeast in Saccharomycetes series that has special usage in biological products production [8]. Hanseniaspora opuntiae yeast is unicellular fungi that divide asexually by budding or fission and whose individual cell size with a large diameter of $5-10 \mu \mathrm{m}$ and a small diameter of $1-7 \mu \mathrm{m}$. The cells of $S$. cerevisiae are pigmented, where cream color may be visualized in surface-grown colonies [9]. In order to increase the ethanol production efficiency of yeast, it is necessary to optimize parameters that affect the process of fermentation [10].

\section{MATERIAL AND METHOD}

The utilized strain in this study was Iranian native strain of Hanseniaspora opuntiae, that was separated from being corrupted grapes after sampling and screening. In order to optimize the conditions of ethanol production and to gain maximum production rate by yeast strain, test design method with Response Surface Method was used, aiming at achieving better results, saving time and material, significant decrease in the number of tests and optimizing production conditions. At first, using the Placket-Burman option of Minitab ${ }^{\circ}$ software, effectual factors were screened with. It is worth mentioning, as in design method tests, two ranks were considered to study qualitative factors like carbon and nitrogen supply, the effect of the sources was investigated by one factor at the time method.

\section{Evaluating the amount of produced ethanol by the presence of different carbon sources}

To choose the best carbon source to produce ethanol, different carbon sources like glucose, sucrose, fructose syrup, glucose syrup, molasses and whey were used. Each of these carbon sources were sterilized in autoclave at $110{ }^{\circ} \mathrm{C}$ for 10 min and then they were added to YPD culture medium ( $1 \%$ yeast extract, $2 \%$ peptone, $2 \%$ glucose, in distilled water). Then, these mediums with different carbon sources, were inseminated with $5 \mathrm{ml}$ yeast suspension with $0.5 \mathrm{McFarland}$ turbidity and $3 \%$ compactness, after they heated up in Incubator shaker under $30^{\circ} \mathrm{C}$ and $150 \mathrm{rpm}$. After 28 hours of insemination, each of fermented environments with different carbon sources were evaluated by hplc (Highperformance liquid chromatography).

\section{Evaluating the amount of produced ethanol in the presence of different nitrogen sources}

In order to determine the best nitrogen source for ethanol production in fermented environments in the presence of optimal carbon source, different nitrogen sources such as ammonium phosphate, ammonium sulfate, industrial urea, ammonium nitrate were used. After preparing culture mediums and sterilizing in autoclave, fermented environments inseminated with $5 \mathrm{ml}$ cell suspension with $0.5 \mathrm{McFarland}$ turbidity and 3\% compactness and then heated up in Incubator shaker with $30^{\circ} \mathrm{C}$ and $150 \mathrm{rpm}$. After 28 hours of heating up, 
the amount of produced ethanol was evaluated with colorimetric method in hplc. In each case, three samples were prepared for each measurement.

\section{RESULTS}

\section{Evaluating the amount of produced ethanol by in presence of different carbon sources}

The amount of produced ethanol in each fermented environment with specific carbon sources (glucose, sucrose, fructose syrup, glucose syrup, molasses and whey) were investigated (Fig. 1). The results showed that the amount of ethanol production by this strain in the presence of sucrose (Fig. 2) and fructose syrup was more than other sources. Also, the least amount of ethanol production by this yeast was in culture medium with whey in the fermentation process.

\section{Evaluating the amount of produced ethanol by the presence of different nitrogen sources}

In order to define the best nitrogen source for ethanol production in fermentation medium by our strain, in the presence of optimal carbon source, the amount of ethanol production in each fermentation medium measured. For instance, the chromatogram of Ethanol production of ammonium nitrate source has shown in Fig. 3. The results of the tests showed that this strain of Hanseniaspora opuntiae has the highest yield for fermentation and ethanol production

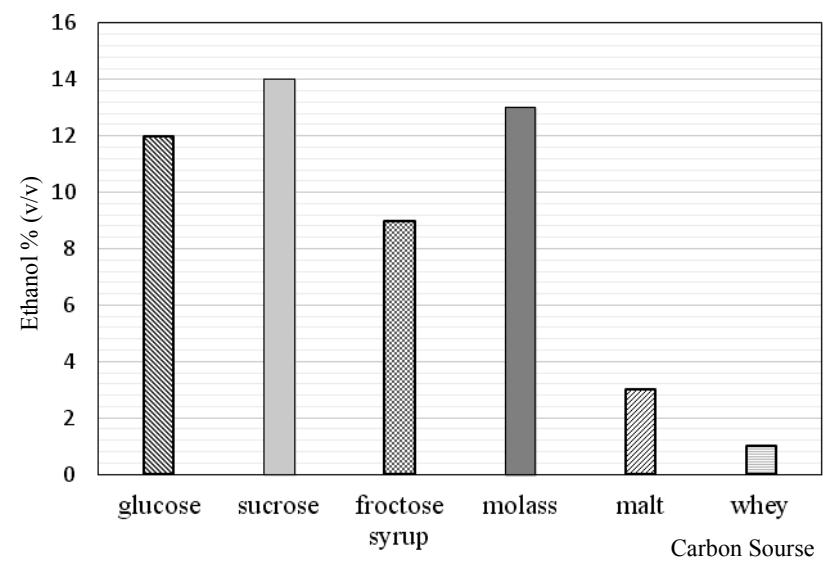

Fig. 1. The amount of ethanol production in the presence of different carbon sources

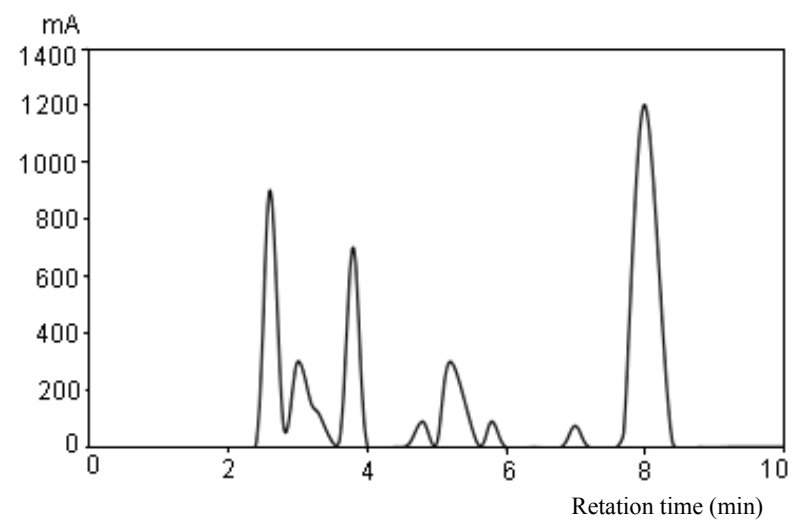

Fig. 3. Chromatogram of ethanol production in the presence of the ammonium nitrate as nitrogen source. The peak number 3 is the peak of evidence of ethanol in presence of peptone sulfate and ammonium nitrate respectively. Moreover, the lowest amount of ethanol production with this strain was when urea used as the source of nitrogen in the culture medium (Fig. 4).

\section{Screening effectual factors in the process of ethanol fermentative production}

In the phase of optimizing the conditions of ethanol production, in order to saving time, significant reduction in the number of tests and therefore reducing the costs of the optimizing stages, screening effectual factors was done by Minitab software with Placket-burman statistical method (Table 1)

Then, in the next stage the designed tests in the previous stage, were empirically studied in the real lab conditions and the results were fed into the Minitab to analyze and determining effectual factors (Table 2).

The results of the designed analysis by the software showed that in considering $\alpha=0.05$, carbon, nitrogen and temperature are three factors that influence ethanol production, while $\mathrm{pH}$ doesn't have significant effect on ethanol production by Hanseniaspora opuntiae (Fig. 5).

Moreover, the results showed that the amount of ethanol production by this strain in the presence of sucrose was more than glucose, in the presence of ammonium nitrate was more than ammonium sulfate, and increased in $30^{\circ} \mathrm{C}$ comparing to $37^{\circ} \mathrm{C}$ (Fig. 6).

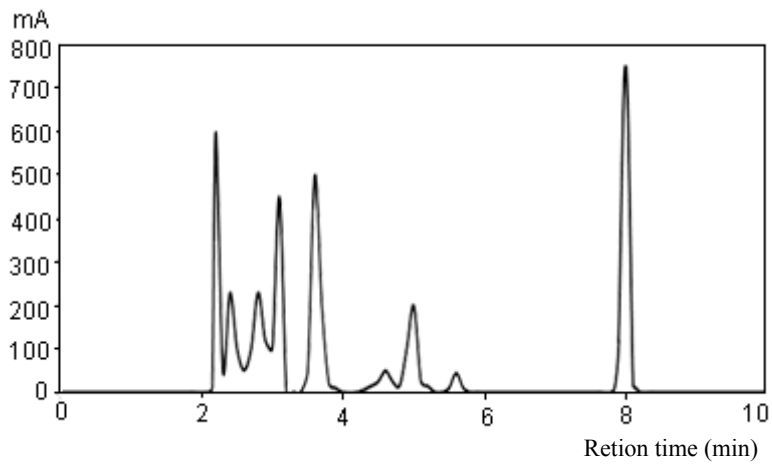

Fig. 2. Chromatogram of HPLC of the sucrose, the peak number 4 caused by ethanol

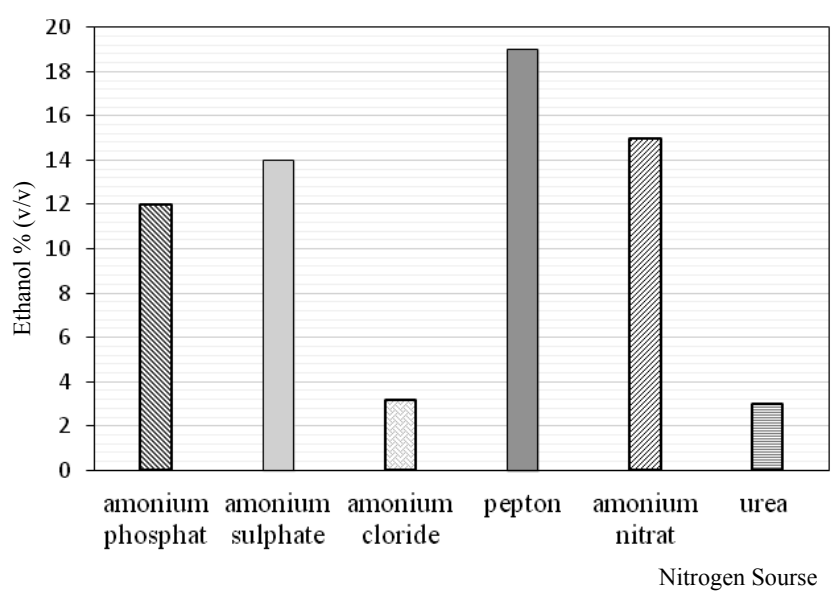

Fig. 4. The amount of produced ethanol in the presence of different nitrogen sources 
Designed tests with Plackett-burman statistical method

Table 1

\begin{tabular}{|c|c|c|c|c|c|c|c|}
\hline Std Order & Run Order & Pt Type & Blocks & Source of C & Source of N & $\mathrm{pH}$ & Temperature, ${ }^{\circ} \mathrm{C}$ \\
\hline 6 & 1 & 1 & 1 & sucrose & ammonium nitrat & 7 & 30 \\
\hline 4 & 2 & 1 & 1 & sucrose & ammonium sulphate & 7 & 37 \\
\hline 9 & 3 & 1 & 1 & glucose & ammonium sulphate & 3 & 37 \\
\hline 1 & 4 & 1 & 1 & sucrose & ammonium sulphate & 7 & 30 \\
\hline 7 & 5 & 1 & 1 & glucose & ammonium nitrat & 7 & 37 \\
\hline 3 & 6 & 1 & 1 & glucose & ammonium nitrat & 7 & 3 \\
\hline 10 & 7 & 1 & 1 & sucrose & ammonium sulphate & 3 & 37 \\
\hline 8 & 8 & 1 & 1 & glucose & ammonium sulphate & 7 & 37 \\
\hline 12 & 9 & 1 & 1 & glucose & ammonium sulphate & 3 & 30 \\
\hline 2 & 10 & 1 & 1 & sucrose & ammonium nitrat & 3 & 37 \\
\hline 11 & 11 & 1 & 1 & glucose & ammonium nitrat & 3 & 30 \\
\hline 5 & 12 & 1 & 1 & sucrose & ammonium nitrat & 3 & 37 \\
\hline
\end{tabular}

Output of the Plackett-burman method after inputting the results of the conducting experiments

Table 2 in the real lab conditions

\begin{tabular}{|c|c|c|c|c|c|c|c|c|}
\hline Std Order & Run Order & Pt Type & Blocks & Source of C & Source of N & $\mathrm{pH}$ & Temperature, ${ }^{\circ} \mathrm{C}$ & Responce \\
\hline 6 & 1 & 1 & 1 & sucrose & ammonium nitrat & 7 & 30 & 800 \\
\hline 4 & 2 & 1 & 1 & sucrose & ammonium sulphate & 7 & 37 & 550 \\
\hline 9 & 3 & 1 & 1 & glucose & ammonium sulphate & 3 & 37 & 220 \\
\hline 1 & 4 & 1 & 1 & sucrose & ammonium sulphate & 7 & 30 & 560 \\
\hline 7 & 5 & 1 & 1 & glucose & ammonium nitrat & 7 & 37 & 600 \\
\hline 3 & 6 & 1 & 1 & glucose & ammonium nitrat & 7 & 30 & 670 \\
\hline 10 & 7 & 1 & 1 & sucrose & ammonium sulphate & 3 & 30 & 600 \\
\hline 8 & 8 & 1 & 1 & glucose & ammonium sulphate & 7 & 37 & 70 \\
\hline 12 & 9 & 1 & 1 & glucose & ammonium sulphate & 3 & & 30 \\
\hline 2 & 10 & 1 & 1 & sucrose & ammonium nitrat & 3 & 37 & 37 \\
\hline 11 & 11 & 1 & 1 & glucose & ammonium nitrat & 3 & 30 & 750 \\
\hline 5 & 12 & 1 & 1 & sucrose & ammonium nitrat & 3 & & 37 \\
\hline
\end{tabular}

\section{DISCUSSION}

Microorganisms that are used in fermentation process, grow in the which environment that provides its nutrition needs, nutrients in fermentation medium depending yeasts needs and dependences divide into two categories maximum and

\section{Pareto Chart of the Standardized Effect} (response is $\mathrm{Cg}, \alpha=0.05$ )

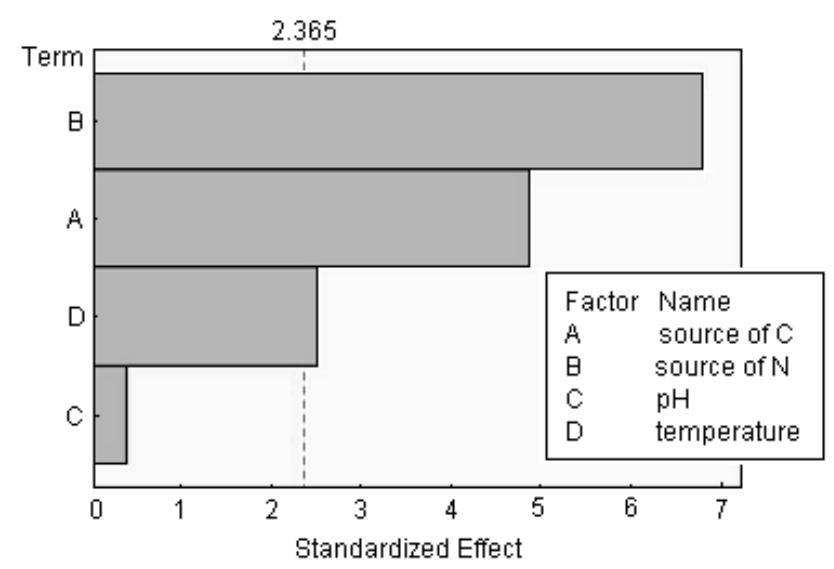

Fig. 5. Effects of carbon, nitrogen, temperature and $p H$ source factors on ethanol production by Hanseniaspora opuntiae minimum elements. Carbon is among maximum ones [11]. Main elements specifically carbon sources needed for fermentation process in laboratory scale, are used in pure form and required amount, which is impossible in industry level. In this study, carbon sources like glucose syrup, sucrose, molasses, malt extract and whey were used as carbon sources. The results showed that the amounts of ethanol production in presence of sucrose and then molasses are respectively higher in comparing to other carbon sources. It seems that the better growth in sucrose presence is due to high purity of its sugar comparing to molasses [12, 13]. The reason of high Efficiency of ethanol production due to fermentation process of molasses comparing to other sources, can be considered that molasses in addition to carbohydrate, contains other essential nutritional sources like amino acids and vitamins like biotin which is a required cofactor in reproduction and accelerating fermentation in yeast $[12,14]$. As in industrial scale one of considerable factors, is the economic benefits, although the present study showed that ethanol production in culture medium with sucrose is more than ethanol production in culture medium with molasses, considering that molasses is cheaper than pure sucrose [11, 15]. Molasses can be a recommended option in industrial usage for fermentation process. The efficiency of Ethanol production from molasses can be improved in the presence of other organic materials $[16,17]$. 


\section{Main Effects Plot for C9}

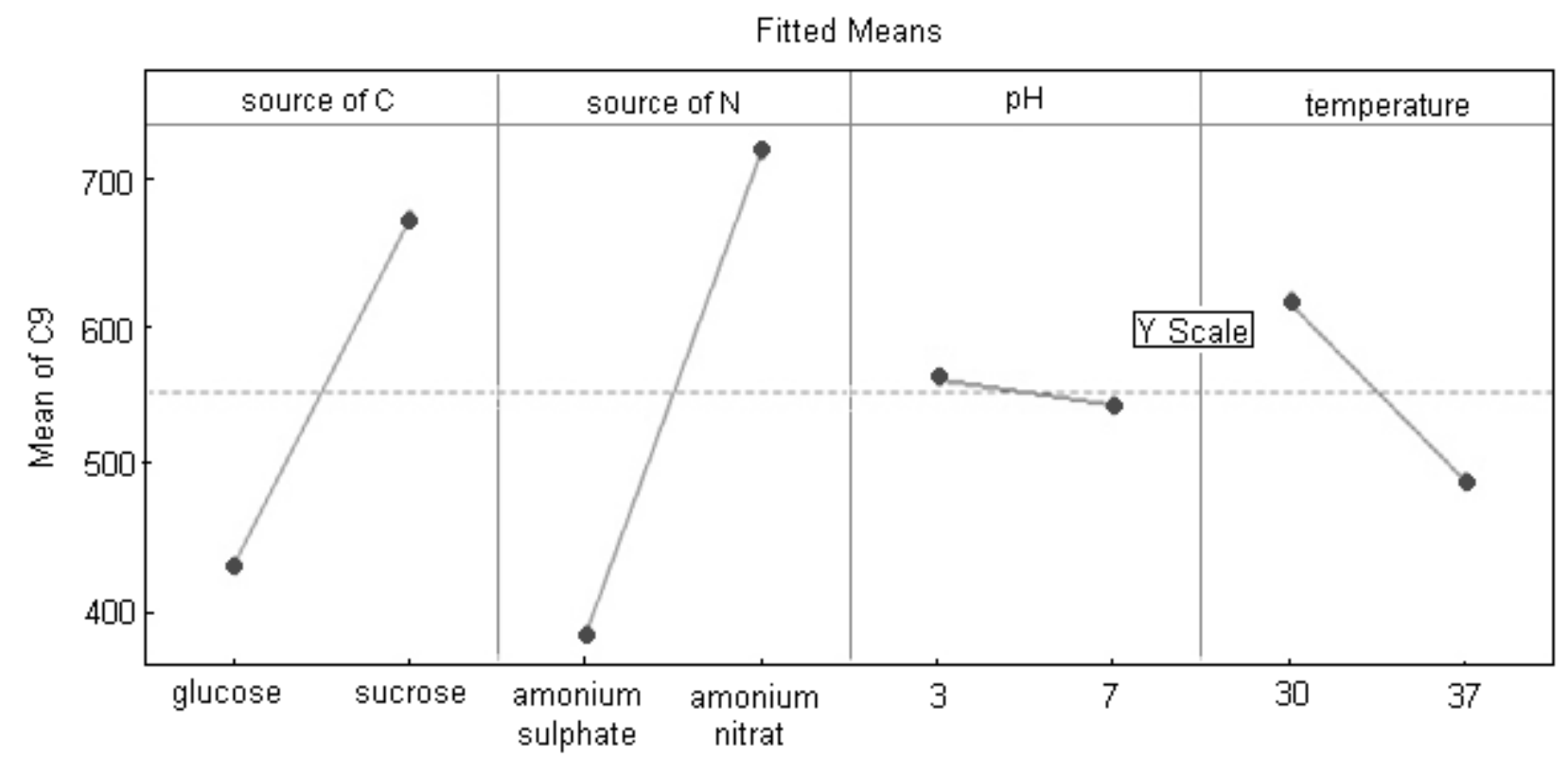

Fig. 6. Presenting the effects of different factors in producing ethanol by Hanseniaspora opuntiae

Yeast extract provides essential necessities like vitamins and cofactors [18], then nitrogen source of yeast extract with second nitrogen source were used for optimization; the results of the study showed that the presence of nitrogen source of yeast extract with peptone leads to the highest ethanol production, in this case the results of the study showed that, although using peptone as nitrogen source cause about $4 \%$ outcome increase in ethanol production, in compare with ammonium nitrate, but as its price is several times higher than the price of ammonium nitrate [19]. So here from economical point of view the difference in production efficiency between peptone ammonium nitrate is not enough much to introduce peptone as better source. But it's shown by this study that ammonium nitrate in comparing to urea leads th fifth times more amount of ethanol production by the yeast and it is also cheaper than urea $[11,20]$. Then based on gained result ammonium nitrate has preference as industrial source of nitrogen to be used in fermentation process by Hanseniaspora opuntiae.

\section{Acknowledgements}

The authors would like to thank Prof. Morovvati and Dr. Heidari for their technical assistance. We also thank Dr. Mohammadi-pur and Iranian Biological Resource Center (IBRC) for their scientific guidance.

\section{References}

1. Shuhaili A., Ihsan F. A., Waleed S. Air pollution study of vehicles emission in high volume traffic: Selangor, Malaysia as a case study. WSEAS Transactions on Systems. 2013. V. 12. P. 67-84.

2. Demirbas A. Biofuels sources, biofuel policy, biofuel economy and global biofuel projections. Energy Conversion and Management. 2008. V. 49. P. 2106-2116.

3. Gnansounou E., Dauriat A. Ethanol fuel from biomass: A review. J Sci Ind Res. 2005. V. 64. P. 809-821.

4. Nurhayati J., Mayzuhroh A., Arindhani S., Caroenchai C. Studies on bioethanol production of commercial baker's and alcohol yeast under aerated culture using sugarcane molasses as the media. Agricultural Science Procedia. 2016. V. 9. P. 493-499

5. Raffaela Cutzu., Laura Bardi. Production of bioethanol from agricultural wastes using residual thermal energy of a cogeneration plant in the distillation phase. Fermentation. 2017. V. 24. P. 153-166

6. M. Hanif., T. M Mahlia., H. B Aditiya., M. S AbuBakar. Energy and environmental assessments of bioethanol production from Sri Kanji cassava in Malaysia. Biofuel Research Journal. 2017. V. 13. P. 537-544

7. Vanda Renata Reis., Ana Paula Guarnieri Bassi., Jessica Carolina Gomes da Silva., Sandra Regina Ceccato-Antonini. Characteristics of Saccharomyces cerevisiae yeasts exhibiting rough colonies and pseudohyphal morphology with respect to alcoholic fermentation. Brazilian Journal of Microbiology. 2013. V. 44. P. 1121-1131

8. Li M., Nielsen J., Borodina I. Engineering of Saccharomyces cerevisiae for production of resveratrol and its derivatives. Horsholm: Novo Nordisk Foundation Center for Biosustainability. PhD thesis 2016

9. Walker G. M., White N. A. Introduction to Fungal Physiology. Fungi: Biology and Applications. 2011. V. 42. P. 1-36

10. Schmidt F. Optimization and scale up of industrial fermentation processes. Appl. Microbiol. Biotechnol. 2005. V. 68. P. 425-435.

11. Teng Li., Xiang-bin Chen., Jin-chun Chen., Qiong Wu., Guo-Qiang Chen. Open and continuous fermentation: Products, conditions and bioprocess economy. Biotechnol. J. 2014. V. 9. P. 1503-1511.

12. Graeme M Walker., Graham G Stewart. Saccharomyces cerevisiae in the Production of Fermented Beverages. Beverages J. 2016. V. 30. P. 97-109.

13. Bagag B K., Taank V., Thakur R L. Characterization of Yeasts for Ethanolic Fermentation of Molasses with High Sugar Concentrations. Journal of Science and Industrial research. 2003. V. 62. P. 1079-1085.

14. Bakhiet Sh., Abdalrhim M. Production of Bioethanol from Molasses by Schizosaccharomyces Species. Annual Research \& Review in Biology. 2015 V. 7. P. 45-53.

15. Muhammad Arshad., Tariq Hussain., Munawar Iqbal., Mazhar Abbas. Enhanced ethanol production at commercial scale from 
molasses using high gravity technology by mutant S. cerevisiae. Brazilian Journal of microbiology. 2017. V. 48. P. 403-409.

16. Thenmozhi C., Sankar R., Karuppiah V., Sampathkumar P. L-asparaginase production by mangrove derived Bacillus cereus MAB5: optimization by response surface methodology. Asian Pac. J. Trop. Biomed. 2011. V. 4. P. 486-491.

17. Abdolbasit M., Gasmalla A., Yang R., Nikoo M., Man S. Production of ethanol from sudanese sugar cane molasses and evaluation of its Quality. Jurnal food processing and technology. 2012. V (3) issue 7. P. 311-320.

18. T vukasinovic., M Rakin., slavica siler-marinkovic. Utilization of baker's yeast (Saccharomyces cerevisiae) for the production

\section{Сведения об авторах}

\section{Кешткар Саид}

аспирант кафедры пищевой биотехнологии Калининградского государственного технического университета,

236022, Калининград, Советский пр., 1 ,

keshtkar.bio@gmail.com

\section{Мезенова Ольга Яковлевна}

д. т. н., профессор кафедры пищевой биотехнологии

Калининградского государственного технического университета, 236022, Калининград, Советский пр., 1, mezenova@klgtu.ru

\section{Хусейни Саба}

аспирант кафедры биотехнологии, Университет Алзахра, 1993893973, Иран, г. Тегеран, ул. Дех-Ванак,

saba.hoseyny@gmail.com

\section{Ромиани Эхсан}

аспирант кафедры гистологии, Тегеранский университет, 1417466191, Иран, г. Тегеран, ул. Азар, eroomiani@ut.ac.ir of yeast extract: effects of different enzymatic treatments on solid, protein and carbohydrate recovery. J. Serb. Chem. Soc. 2007. V. 72. P. 451-457.

19. Pavlecic M. Ethanol production from different intermediates of sugar beet processing. Food Technology and Biotechnology. 2010. V. 48 (3). P. 362-367.

20. T Sahar., M Anjum., Anum S., M Salman., S Aleem., R Iqbal., N Rafiq., H N Majeed., I Javed. Comparative study for optimization of nutritional parameters for enhanced production of glucose oxidase from wild and mutants strains of A. niger. Advances in Applied Science Research. 2017. V. 8 (4). P. 1-13.

\section{Information about authors}

\section{Keshtkar Saeid}

$\mathrm{Ph}$. D student of the Department of Food Biotechnology,

Kaliningrad State Technical University,

Russia, 236022, Kaliningrad, Sovetskiy pr. 1,

keshtkar.bio@gmail.com

\section{Mezenova Olga Yakovlevna}

D. Sc., Professor of the Department

of Food Biotechnology, Kaliningrad State Technical University,

Russia, 236022, Kaliningrad, Sovetskiy pr. 1,

mezenova@klgtu.ru

\section{Hosseini Saba}

$\mathrm{Ph}$. D student of Biotechnology Departrment, Alzahra University, 1993893973, Iran, Tehran, Deh-e-Vanak Str., saba.hoseyny@gmail.com

\section{Romiani Ehsan}

$\mathrm{Ph}$. D student of Comparative Histology Department, 1417466191, Tehran University, Iran, Tehran, 16th Azar Str, eroomiani@ut.ac.ir

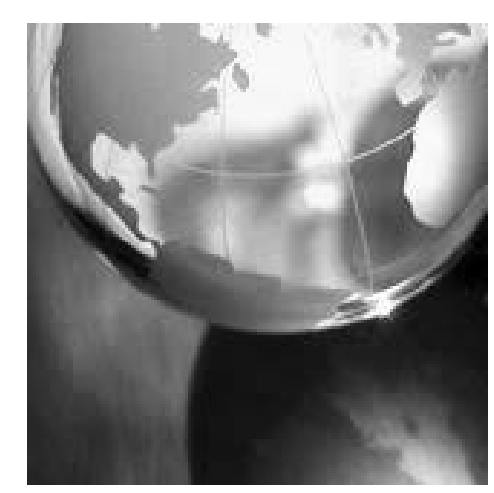

28th International Conference

Ecology \& Safety

28 June - 2 July 2019

Burgas, Bulgaria

http://www.sciencebg.net

\section{8 Международная конференция \\ Экология и безопасность}

\author{
28 июня - 2 июля 2019 г. \\ Бургас, Болгария
}

Тематика конференции:

- Энергия, климат и глобальная безопасность в 21-ом столетии;

- Экология воздуха, почвы и воды;

- Экология человека - здоровье и безопасность;

- Гражданская оборона и борьба со стихийными бедствиями.

\section{Topics:}

- Energy, Climate and Global Security in the 21st Century;

- Ecology of Air, Soil and Water;

- Health and Safety;

- Civil Protection and Disaster Management. 